\title{
Constraint Analysis of the Farm Innovators in Southern Karnataka, India
}

\author{
C.V. Sanketh, K.P. Raghuprasad and Tanweer Ahmed* \\ Department of Agricultural Extension, University of Agricultural Sciences, \\ GKVK, Bengaluru, India \\ *Corresponding author
}

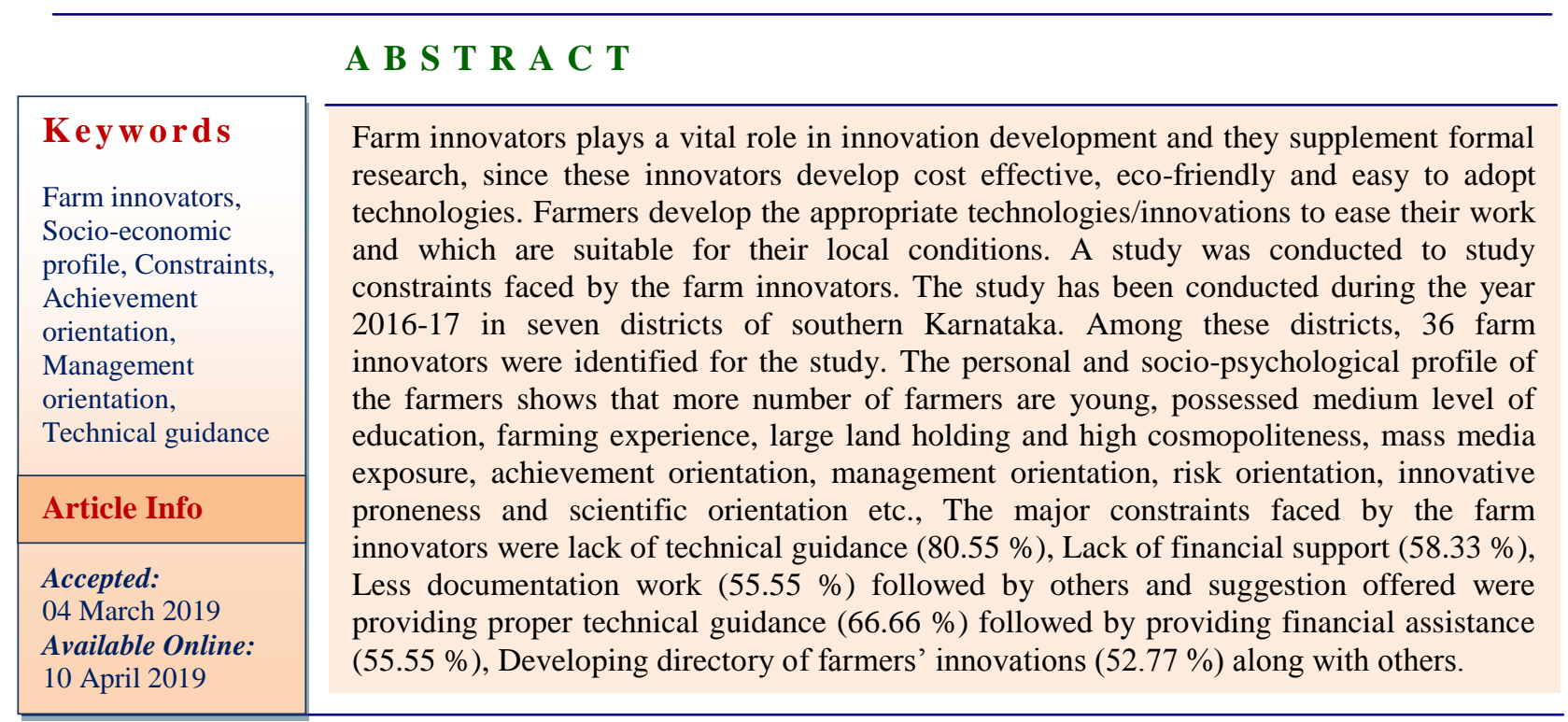

\section{Introduction}

Development of agricultural sector is driven by innovation at all levels. Until recently, very little attention was given to the new technologies, management practices and institutions that farmers and farming communities have developed themselves over time within a local setting incorporating both learning from the experience of earlier generations and knowledge.

In the course of time, farmers have come out with numerous innovations, which brought them good returns and made farming a profitable one. Farmers have developed new and low-cost technologies for sustainable production of crops, animal husbandry, processing, packaging and preserving various farm products both for increased self-life and better market opportunities. The ultimate aim of any farmers' innovation is to overcome the problem. Despite this, the innovations made by farmers have not received the recognition, which they deserve. Also, the property rights on the innovations made by the farmers have often been ignored. In order to promote the development of farmer led skills as well as to 
protect their rights, it is necessary to recognize and further promote these innovations.

Farm innovators is a term used here to denote natural resource users/managers, such as cultivators, livestock keepers, forest users, and fisher folk have been carrying out most of the experimentation, discovery, innovation and adaptation in agriculture and allied sector since time immemorial. Before formal research and extension services existed, farmers own experimentation allowed them to adopt these in varied situations and thus to survive. Sometimes because of sheer necessity, out of curiosity or by accident, farmers have come up with new ways to improve their farming practices.

Farm innovation in agriculture is the process through which individuals or groups within a given locality discover or develop and apply improved ways of managing the available resources, building on and expanding the boundaries of their indigenous knowledge. According to Anonymous (2004) and the Anonymous(2006), farm innovation refers to the dynamics of indigenous knowledge i.e., knowledge that grows within a social group, incorporating learning from own experience over generations, but also external knowledge internalized within the local ways of thinking and doing.

All farmers' innovations may not be of a technical nature but rather to improve socioeconomic status of the farmers. The concept of farmer innovation is applied to agriculture technology processes that aim to improve rural livelihoods for sustainable development while ensuring inter-institutional and farmer learning.

With this background the study was conducted to know the socio-economic profile and constraints of the farm innovators in
Southern Karnataka which includes socioeconomic characteristics of the farm innovators, constraints faced by the farm innovators in developing farm innovations and also it include suggestions offered by the farm innovators to overcome the constraints.

\section{Materials and Methods}

An Ex-post facto research design was followed to know the socio-economic profile and constraints faced by the farm innovators. Seven districts of southern Karnataka viz., Mysore, Mandya, Ramanagara, Chamarajnagar, Bengaluru rural, Tumkur, Hassan were selected.

The farm innovators were identified in consultation with the officials of Krishi Vignan Kendras (KVK's), Department of Agriculture, Department of Horticulture, other local institutions and NGO's in the selected districts for further documentation work. A final sample of 36 farm innovators and 50 farmers' innovations were considered for the study. Statistical tools like Frequency, Mean, Percentage, Standard Deviation were used for analysis of data.

\section{Results and Discussion}

\section{Personal characteristics of the farm} innovators

Age

Table 1 reveals that about 41.67 per cent of the farm innovators belonged to young age group followed by 33.33 per cent of the farm innovators belonged to middle age group and 25.00 per cent of farm innovators belonged to old age group.

Probable reason for above trend of finding might be due to the fact that most of the young people are interested in doing new 
things, taking the additional income generating activities along with the farming. Another reason may be that young aged are enthusiastic and have more work efficiency than the older or middle ones. Individual may be ready to take more risk in the young age itself. Individuals in young age group have more physical vigour and also more interest to work than the middle and old age group. Further, doing of these innovations are required more scientific orientation and skills as the young age farmers are ready to learn new skills.

\section{Education}

The table 1 shows that about 47.22 per cent of farm innovators had medium level of education followed by 33.33 per cent of farm innovators belonged to higher level of education and 19.45 per cent of farm innovators had low level of education.

It is universal fact that education plays a key role in bringing desirable changes in human beings. As the majority of the farmers are educated, they were able to gather new knowledge and help to do innovations. This finding goes in agreement with that of Chaithra (2014).

\section{Farming experience}

From the table 1 it can be inferred that about one third of farmers $(36.11 \%)$ had medium level of farming experience, whereas 33.33 per cent and 30.56 per cent of the farmers had high and low levels of farming experience, respectively.

The farming experience is one of the important components which help the farmers for the decision making ability in choosing the type of crop to be grown and understanding the local situation and to do the location specific and cost effective innovations. The medium level of farming experience also contributes for taking rational decisions. The findings of the study conducted by Sahana (2013) are in line with the results of the present study.

\section{Family size}

The data in the table 1 indicated that exactly half $(50.00 \%)$ of farmers who are responsible for farmers innovations were having the medium family size followed by small family size $(30.56 \%)$ and farmers having big family size $(19.44 \%)$.

The probable reasons for the findings could be that off late the social structure of the society is moving towards nuclear families because of fragmentation and division of land holding. Further, the social values attached to the joint family system is slowly eroding may be because of the influence of urbanization and cosmopoliteness. The findings are in agreement with the findings of Kale (2008) and Shwetha (2012).

\section{Land holding}

Table 1depicts that about 63.88 per cent of the respondents had larger land holding followed by 25.00 per cent of the respondents had small land holding and 11.12 per cent of the respondents had marginal land holding.

The large farmers who are on the higher strata of the society always venture for new things and aim at wind fall profits. This might have contributed for the above trend and the results are in line with the studies conducted by Saravanan and Veerabhadraiah (2005).

\section{Communication characteristics of the farm} innovators

\section{Mass media exposure}

Table 2 infers that more than half $(55.56 \%)$ of farm innovators had high level of mass 
media exposure, followed by 22.22 per cent of farm innovators had medium and low level of mass media exposure.

The reason might be that the farmers having better exposure to different sources of information will help them to understand the different concepts and new initiatives, hence the present trend might have been observed. The results are in line with the studies of Nagadev and Venkataramaiah (2007).

\section{Extension Contact}

Table 2 shows that nearly half $(47.22 \%)$ of the respondents had high level of extension contact with the extension personnel of agriculture and allied sectors followed by 30.56 per cent of farmers had low level of extension contact and 22.22 per cent of the farmers had medium level of extension contact with the extension personnel of agriculture and allied sectors.

Extension contact results in purposeful action which is largely contingent upon an individual's belief in his ability to perform the action correctly and effectively and thus he frequently contacts various departmental officials to seek more information and to clarify the doubts pertaining to the latest and improved practices and technology. The other reason for this could be the fact that respondents have interest in collecting new information through extension personnel. The results are in line with the findings of Sahana (2013).

\section{Extension participation}

The data in the table 2 revealed that about one third $(36.11 \%)$ of farmers who developed farmers' innovation had high degree of extension participation, about 33.33 per cent of the farmers had low level of extension participation followed by 30.56 percent of the farmers who developed farmers' innovation had medium level of extension participation.

The possible reason might be that usually farm innovators participate voluntarily in the extension activities conducted by different agencies often may be according to the needs and interest of most of the farmers and these farmers act as an opinion leaders in their locality. The results are in line with the studies of Shireeshadevarakonda (2015).

\section{Cosmopoliteness}

A critical analysis of the data in the table 2 reveals that about 38.89 per cent of farmers were having high level of Cosmopoliteness followed by low $(36.11 \%)$ and medium $(25.00 \%)$ level of cosmopoliteness.

It can be concluded that considerable percentages of farmers were high cosmopolite in nature. This might be due to their sound economic conditions, their regular participation in extension activities like field visits, Krishimela and also due to more extension contact which might have led to this kind of result. The results are in conformity with the findings of Suresh (2004) and Vinay (2012).

\section{Psychological characteristics of the farm innovators}

\section{Risk orientation}

Table 3 shows that slightly less than half $(47.22 \%)$ of the farmers had high level of risk orientation, followed by 41.67 and 11.11 per cent of the respondents had medium and low level of risk orientation, respectively.

Risk orientation is the quality of any individual to excel in their activities, which might have influence them to take up new innovations. The reason for this kind of result 
might be that risk bearing capacity of an individual depends upon the personal, psychological, social and economic condition of farmers.

The individual with good education, more farming experience and medium to high land holding and more income might have exhibited high and medium level of risk orientation. These findings are in accordance with the findings of Natikar (2001) and Vinay (2012).

\section{Management orientation}

Table 3 indicated that exactly half of the respondents had high level of management orientation followed by medium (44.44\%) and low $(5.56 \%)$ level of management orientation.

The probable reason for farmers that to fall under the high level of management orientation might be that the personal exposure of farmers to various professional situations like extension meeting, exhibitions, field days, Krishimela etc., also might have contributed to develop a high level of management orientation. The findings were in accordance with the studies conducted by Lavanya (2010).

\section{Achievement motivation}

From the table 3 it can be observed more than half $(58.33 \%)$ of farm innovators had high level of achievement motivation whereas, 22.22 per cent of farm innovators had medium and 19.45 per cent of farm innovators had low level of achievement motivation.

The study were found to have high level of achievement motivation because of their risk taking capability, field visits, extension participation and extension contact had reflected in their innovations to achieve higher economic performance and good yield. The findings are in conformity with the results of the studies conducted by Chandrapaul (1998) and Suresh (2004).

\section{Fatalism-scientism}

Table 3 it reveals that about 41.67 per cent of the respondents had medium level of Fatalism-scientism, whereas 33.33 per cent and 25.00 per cent of the respondents had low and high level of fatalism-scientism.

The study had found above results because usually innovative farmers who are young in age, big farmers, and high achievement oriented farmers were believe in hard work rather than the fate. So the majority of farmers had medium and low fatalism-scientism. The findings are in line with the Somasundaram (1995).

\section{Scientific orientation}

Table 3 indicated that about sixty one per cent of the respondents $(61.11 \%)$ had high scientific orientation followed by low (30.56 $\%)$ and high $(8.33 \%)$ level of scientific orientation.

This indicates that the majority of the respondents view the things scientifically with interest and good knowledge because of their risk taking ability, achievement motivation and cosmopoliteness. Majority of the respondents had high scientific orientation.

This might be due to the reason that they were having an high degree of acceptance of the latest technologies and latest views in agriculture or farming and in the use scientific management practices, in planning, adoption, and monitoring of the farm operations. The results are in line with the studies of Chaithra (2014) 


\section{Innovative proneness}

Table 3 data showed that more than fifty per cent $(55.55 \%)$ of farmers were having high level of innovative proneness, followed by 27.78 per cent of farmers were having medium level of innovative proneness and 16.67 per cent of farmers were having low level of innovative proneness.

Majority of the respondents belonged to high and medium level of innovativeness. This might be due to the reason that about half of the respondents were having medium literacy, eager to learn new things and accept the changes very quickly. Further, high extension contact and extension participation, which might have influenced them to have moderate innovative characteristics of an innovator. The findings were in accordance with the studies conducted by ChandraniSaha (2008).

\section{Constraints faced by the farm innovators}

The constraints faced by farm innovators were expressed in Table 4, A critical analysis of the table shows that Lack of technical guidance (Rank-I) followed by, Lack of financial support (Rank-II), Less documentation work (Rank-III), Lack of family support (Rank-IV), Lack of recognition and support for farmers innovations (Rank-V), Lack of education (Rank-VI), Non availability of required materials for innovations (Rank-VII), social acceptance (Rank-VIII), Chances of uncertainty or failure of innovation (RankIX), Promotional effort for innovations (Rank-X), Lack of practicality (Rank-XI) and Less mass media exposure (Rank-XII) were constraints faced by the farm innovators.

Lack of technical guidance was stated as major constraints faced by the farm innovators, since their innovations are evolved by the farmers themselves and no proper guidance is available from scientists because in most of the case their innovations have not come to the notice of the scientists. Further most of the time even scientists relay upon research findings of formal research system rather than look into farmers' innovations due to the reason that they lack scientific evidences. Similarly lack of mass media exposure was found to be least constraint though the results are contradiction to the results obtained in case of more mass media exposure. The reason may be that the technologies which are broadcasting through mass media are from formal research system and targeted the mass of audience. But same cannot be applicable to the farmers' innovations since these innovations confined to smaller area and these results are in concurrent with the Shireesha Devarakonda (2015).

\section{Suggestions offered by the farm innovators to overcome the constraints faced by them}

Data tabulated in Table 5 indicated the suggestions given by the farm innovators, An analyzed data in the table suggested that, Proper technical guidance (Rank-I) followed by Providing Financial assistance (Rank-II), Developing directory of farmers' innovations (Rank-III), Providing awards and recognition for farmers' innovations (Rank-IV), Requiring of Scientific validation (Rank-V), Involving of extension agency in promotion of successful farmers' innovations (Rank-VI) and Networking of farmers' innovations (Rank-VII) were their suggestions to overcome the problems faced by them.

It is quite obvious that many of farm innovators need to seek technical guidance from scientist to evolve these innovations, to enhance the efficiency and improve the performance of the innovations. Further less number of farm innovators suggested that networking of farmers' innovations is more 
required, since the majority of the farmers scattered at different places who are having mobiles and if proper networking is made they can share the information among themselves. But it is found to be difficult since most of them have poor network connectivity in rural areas and these results are in concurrent with the Shireesha Devarakonda (2015).

Table.1 Personal characteristics of the farm innovators

\begin{tabular}{|c|c|c|c|c|}
\hline Particulars & Category & Number & Percent & \\
\hline \multirow[t]{3}{*}{ Age } & Young $(<41$ years $)$ & 15 & 41.67 & \multirow{3}{*}{$\begin{array}{l}\text { Mean }=40.98 \\
\mathrm{SD}=12.81\end{array}$} \\
\hline & $\begin{array}{l}\text { Middle(more than } \\
42 \& \text { upto } 53 \text { years) }\end{array}$ & 12 & 33.33 & \\
\hline & Old (>53years) & 9 & 25.00 & \\
\hline \multirow[t]{3}{*}{ Education } & Low & 7 & 19.45 & \multirow{3}{*}{$\begin{array}{l}\text { Mean }=4.08 \\
\mathrm{SD}=1.18\end{array}$} \\
\hline & Medium & 17 & 47.22 & \\
\hline & High & 12 & 33.33 & \\
\hline \multirow{3}{*}{ Farming Experience } & Low & 11 & 30.56 & \multirow{3}{*}{$\begin{array}{l}\text { Mean }=26.10 \\
\mathrm{SD}=13.00\end{array}$} \\
\hline & Medium & 13 & 36.11 & \\
\hline & High & 12 & 33.33 & \\
\hline \multirow[t]{3}{*}{ Family size } & Small & 11 & 30.56 & \multirow{3}{*}{$\begin{array}{l}\text { Mean }=6.28 \\
\mathrm{SD}=3.47\end{array}$} \\
\hline & Medium & 18 & 50.00 & \\
\hline & Large/Big & 7 & 19.44 & \\
\hline \multirow[t]{3}{*}{ Land Holding } & $\begin{array}{l}\text { Marginal } \\
\text { farmers }(<2.5 .0 \\
\text { acres })\end{array}$ & 4 & 11.12 & \multirow[t]{3}{*}{$\begin{array}{l}\text { Mean }=8.72 \\
S D=6.15\end{array}$} \\
\hline & $\begin{array}{l}\text { Small farmers }(2.5- \\
5.0 \text { acres })\end{array}$ & 9 & 25.00 & \\
\hline & $\begin{array}{l}\text { Large farmers }(>5.0 \\
\text { acres })\end{array}$ & 23 & 63.88 & \\
\hline
\end{tabular}

Table.2 Communication profile characteristics of the farm innovators

\begin{tabular}{|c|c|c|c|c|}
\hline Particulars & Category & Number & Percent & \\
\hline \multirow{3}{*}{ Mass media exposure } & Low & 8 & 22.22 & \multirow{3}{*}{$\begin{array}{l}\text { Mean }=8.56 \\
\mathrm{SD}=2.08\end{array}$} \\
\hline & Medium & 8 & 22.22 & \\
\hline & High & 20 & 55.56 & \\
\hline \multirow[t]{3}{*}{ Extension contact } & Low & 11 & 30.56 & \multirow{3}{*}{$\begin{array}{l}\text { Mean }=9.28 \\
\mathrm{SD}=3.98\end{array}$} \\
\hline & Medium & 8 & 22.22 & \\
\hline & High & 17 & 47.22 & \\
\hline \multirow{3}{*}{$\begin{array}{l}\text { Extension } \\
\text { participation }\end{array}$} & Low & 12 & 33.33 & \multirow{3}{*}{$\begin{array}{l}\text { Mean }=10.03 \\
\mathrm{SD}=3.18\end{array}$} \\
\hline & Medium & 11 & 30.56 & \\
\hline & High & 13 & 36.11 & \\
\hline \multirow[t]{3}{*}{ Cosmopoliteness } & Low & 13 & 36.11 & \multirow{3}{*}{$\begin{array}{l}\text { Mean=27.22 } \\
\text { S.D=1.94 }\end{array}$} \\
\hline & Medium & 9 & 25.00 & \\
\hline & High & 14 & 38.89 & \\
\hline
\end{tabular}


Table.3 Psychological profile Characteristics of the farm innovators

\begin{tabular}{|c|c|c|c|c|}
\hline Particulars & Category & Number & Percent & \\
\hline \multirow{3}{*}{ Risk Orientation } & Low & 4 & 11.11 & \multirow{3}{*}{$\begin{array}{l}\text { Mean }=5.92 \\
\text { S.D }=0.37\end{array}$} \\
\hline & Medium & 15 & 41.67 & \\
\hline & High & 17 & 47.22 & \\
\hline \multirow{3}{*}{$\begin{array}{l}\text { Management } \\
\text { orientation }\end{array}$} & Low & 2 & 05.56 & \multirow{3}{*}{$\begin{array}{l}\text { Mean }=17.67 \\
\text { S.D }=1.37\end{array}$} \\
\hline & Medium & 16 & 44.44 & \\
\hline & High & 18 & 50.00 & \\
\hline \multirow{3}{*}{$\begin{array}{l}\text { Achievement } \\
\text { motivation }\end{array}$} & Low & 7 & 19.45 & \multirow{3}{*}{$\begin{array}{l}\text { Mean }=23.08 \\
\text { S.D }=3.52\end{array}$} \\
\hline & Medium & 8 & 22.22 & \\
\hline & High & 21 & 58.33 & \\
\hline \multirow[t]{3}{*}{ Fatalism-scientism } & Low & 12 & 33.33 & \multirow{3}{*}{$\begin{array}{l}\text { Mean }=25.92 \\
\text { S.D }=2.57\end{array}$} \\
\hline & Medium & 15 & 41.67 & \\
\hline & High & 9 & 25.00 & \\
\hline \multirow[t]{3}{*}{ Scientific orientation } & Low & 11 & 30.56 & \multirow{3}{*}{$\begin{array}{l}\text { Mean }=24.00 \\
\text { S.D }=1.76\end{array}$} \\
\hline & Medium & 3 & 08.33 & \\
\hline & High & 22 & 61.11 & \\
\hline \multirow[t]{3}{*}{ Innovative proneness } & Low & 6 & 16.67 & \multirow{3}{*}{$\begin{array}{l}\text { Mean=22.69 } \\
\text { S.D }=3.14\end{array}$} \\
\hline & Medium & 10 & 27.78 & \\
\hline & High & 20 & 55.55 & \\
\hline
\end{tabular}

Table.4 Constraints Faced by the farm innovators

\begin{tabular}{|l|c|c|c|}
\hline \multicolumn{1}{|c|}{ Constraints } & Frequency * & Percentage & Rank \\
\hline Lack of technical guidance & 29 & 80.55 & I \\
\hline Lack of financial support & 21 & 58.33 & II \\
\hline Less documentation work & 20 & 55.55 & III \\
\hline Lack of family support & 19 & 52.77 & IV \\
\hline $\begin{array}{l}\text { Lack of recognition and support } \\
\text { for farmers innovations }\end{array}$ & 17 & 47.22 & V \\
\hline Lack of education & 16 & 44.44 & VI \\
\hline $\begin{array}{l}\text { Non availability of required } \\
\text { materials for innovations }\end{array}$ & 15 & 41.66 & VII \\
\hline social acceptance & 12 & 33.33 & VIII \\
\hline $\begin{array}{l}\text { Chances of uncertainty or failure of } \\
\text { innovation }\end{array}$ & 11 & 30.55 & IX \\
\hline Promotional effort for innovations & 9 & 25.00 & X \\
\hline Lack of practicality & 8 & 22.22 & XI \\
\hline Less mass media exposure & 6 & 16.66 & XII \\
\hline
\end{tabular}

*multiple responses 
Table.5 Suggestions offered by farm innovators

\begin{tabular}{|l|c|c|c|}
\hline \multicolumn{1}{|c|}{ Suggestions } & Frequency * & Percentage & Rank \\
\hline Proper technical guidance & 24 & 66.66 & I \\
\hline Providing Financial assistance & 20 & 55.55 & II \\
\hline $\begin{array}{l}\text { Developing directory of farmers } \\
\text { innovations }\end{array}$ & 19 & 52.77 & III \\
\hline $\begin{array}{l}\text { Providing awards and recognition } \\
\text { for farmers innovations }\end{array}$ & 18 & 50.00 & IV \\
\hline $\begin{array}{l}\text { Requiring of Scientific validation } \\
\text { Involving of extension agency in } \\
\text { promotion of successful farmers } \\
\text { innovations }\end{array}$ & 16 & 44.44 & V \\
\hline $\begin{array}{l}\text { Networking of farmers } \\
\text { innovations }\end{array}$ & 15 & 41.66 & VI \\
\hline
\end{tabular}

*Multiple responses

Based on the result of the study it can be concluded that innovativeness plays major role in the generation of innovations by the farmers. Hence, there is need to encourage their innovations by the concerned organizations. Further these innovations may be tested, other parts of the state with similar conditions in order to generalize its utility and application. Also there is need to document these farmers' innovations and publicise it to farming community. Also the present investigation reveals that none of the farmers' innovations have reached the stage of commercialisation. Hence, the concerned agencies should make an attempt to protect the intellectual property rights of farmer innovators and facilitate in applying patenting for intellectual property rights if required.

\section{References}

Anonymous, 2004, Promoting local innovation: enhancing IK dynamics and links with scientific knowledge, http://www.worldbank.org/afri/ik/defa ult.html

Anonymous, 2006, Prolinnova- Ethiopia progress report, www.prolinnova.net

Chaithra, G. J., 2014, An impact analysis of
Sujeevana programme of Initiatives for Development Foundation (IDF) on beneficiary farmers of Tumkur district. M.Sc. (Agri.) Thesis (Unpub.), Univ. Agri. Sci., Bangalore.

Chandrani Saha., 2008, A study on sustainability of farming systems and livelihood security among rural households in Tripura. M.Sc. (Agri) Thesis (Unpub.), Univ. Agri. Sci, Bangalore.

Chandrapaul, K., 1998, A study on entrepreneurial behavior of vegetable growers in Krishana district of Andra Pradesh. M. Sc. (Agri.) Thesis (Unpub.), Acharya N.G. RangaAgric. Univ. Hydrabad.

Kale, N. M., 2008, Socio-economic, psychological and situational causes of suicides of farmers in Vidarbha region. Ph. D. Thesis (Unpub.), Panjabrao Deshmukh Krishi Vidyapeeth, Akola.

Lavanya, B. T., 2010, Assessment of farming system efficiently in Theni district of Tamil Nadu. M.Sc. (Agri.)Thesis (Unpub.), Univ. Agri. Sci., Bangalore.

Nagadev, B. and Venkataramaiah, P., 2007, Characteristics of integrated 
pestmanagement (IPM) trained dry paddy farmers. The Andhra Agric. J., 54(3\&4): 240-242.

Natikar, K. V., 2001, Attitude and use of farm journal by the subscribers farmers and their profile. A critical analysis. Ph. D. Thesis (Unpub.), Univ. Agri. Sci., Dharwad.

Sahana, S., 2013, A study on contract farming in Karnataka. Ph.D. (Agri.) Thesis (Unpub.), Univ. Agri. Sci., Bangalore.

Saravanan, R. and Veerabhadraiah, V., 2005, Clientele of public, private and NGO's agricultural extension. Indian J. Ext. Edu., 41 (1\&2): 48-50.

Shireesha Devarakonda, 2015, A study on generation of farmer innovations and re-inventions in Andhrapradesh, $P h$. D. Thesis (Unpub.), PJTSAU, Hyderabad.
Shwetha, B.M., 2012, Comparative analysis of integrated farming systems practiced by farmers in Mandya district. M. Sc. (Agri) Thesis (Unpub.), Univ. Agri. Sci., Bangalore.

Somasundaram, S., 1995, Indigenous knowledge in farming systems.Ph. D. Thesis (Unpub.), TNAU, Coimbatore.

Suresh, 2004, Entrepreneurial behavior of milk producers in Chittoor district of Andhra Pradesh - A critical study. $M$. V. Sc. Thesis (Unpub.), ANGRAU, Hyderabad.

Vinay Kumar, H. M., 2012, Impact of community based tank management on socioeconomic status and crop productivity of beneficiary farmers in Tumkur district. M. Sc. (Agri.) Thesis (Unpub.), Univ. Agri. Sci., Bangalore.

\section{How to cite this article:}

Sanketh, C.V., K.P. Raghuprasad and Tanweer Ahmed. 2019. Constraint Analysis of the Farm Innovators in Southern Karnataka, India. Int.J.Curr.Microbiol.App.Sci. 8(04): 13-22. doi: https://doi.org/10.20546/ijcmas.2019.804.002 